\title{
Studia
}

\section{Łukasz Garbal}

\section{Inteligent na strajku. Jan Józef Lipski w grudniu 1981 roku}

\author{
Intelligent on strike. Jan Jozef Lipski in December 1981
}

\begin{abstract}
The article is an attempt to determine the source of the facts relating to the strike in the Mechanical Works „Ursus” after the introduction of martial law in communist Poland and break the strike by force by the authorities and the fate of the leaders of the protest, with particular emphasis on advising the leaders of the strike long-term dissident, Jan Jozef Lipski. The author juxtaposes different relationships, and, critically reviewing them, trying to reach witnesses from different levels of decision-making.
\end{abstract}

Keywords - the state of war, strike, Ursus, Solidarity

W nocy z 14 na 15 grudnia 1981 roku Jan Józef Lipski został aresztowany, a później uwięziony w areszcie śledczym na ul. Rakowieckiej, po złamaniu strajku Solidarności w Zakładach Mechanicznych „Ursus”. Jak do tego doszło? Lipski nie został internowany - minął się z funkcjonariuszami SB na schodach do swojego mieszkania ${ }^{1}$. Nocował w mieszkaniu koleżanki z PIW-u, Krystyny Podgóreckiej². W poniedziałek 14 grudnia poszedł rano do IBL-u, gdzie, „bodaj jedyny raz w życiu [...] tak silnie zdenerwowanego” widział go Michał Głowiński. „Chyba na kogoś czekał, mówił, że musi się przedostać do robotników z Ursusa. Tam właśnie go aresztowano”3.

Imperatyw moralny: „sprawą honoru było nie kryć się...”

Dlaczego Lipski chciał dotrzeć właśnie do zakładów w Ursusie? Była to wówczas największa fabryka w Warszawie. Po protestach robotników z Radomia i Ursusa z czerwca 1976 roku powstał KOR, niosac im pomoc. Zakłady w Ursusie strajkowały też latem 1980 r. (już 1 lipca 1980 roku, w reakcji na wejście w życie podwyżki cen mięsa i wędlin); stały się później podporą Solidarności na Mazowszu. W jednej z prac dyplomowych powstałych w Wyższej Szkole Oficerskiej MSW w Legionowie czytamy, że Ursus to ok. 16 tys. załogi znanej „z rewolucyjnych wręcz wystapień i pozostająca pod najsilniejszym zawsze oddziaływaniem opozycji. [...] Od niego zaczynały się inicjowane w tamtym okresie przez region akcje strajkowe i protestacyjne, on »promieniował na inne zakłady pracy"4.

\footnotetext{
${ }^{1}$ J.J. Lipski, Wyznania, przygotowała i oprac. M.D. Pieńkowska, „Polityka” 1992 nr 3.

2 Relacja Krystyny Podgóreckiej, 8 października 2009 r.

${ }^{3}$ M. Głowiński, Kregi obcości. Opowieść autobiograficzna, Kraków 2010, s. 418.

${ }^{4}$ B. Sieradzki, Zwalczanie nielegalnej działalności NSZZ ,Solidarnośc”” w obiektach gospodarki narodowej w latach 1981-1984 na praylktadzie Zakładón Mechanicznych „Ursus”, praca dyplomowa, Warszawa 1989 (Archiwum Instytutu Pamięci Narodowej - dalej: AIPN,
} 
Z tych zakładów wywodził się przewodniczący Regionu, Zbigniew Bujak; wiele razy miały tu miejsce strajki i wiece - to tu przyjechał Wałęsa na wiec po złożeniu wniosku o rejestrację Solidarności, przyjeżdżali Jacek Kuroń i Adam Michnik. Strajkowano w obronie Jana Narożniaka i Piotra Sapełły; strajkowano też 22 stycznia 1981 roku (9 tysięcy pracowników) 5. W marcu, podczas kryzysu bydgoskiego, szykowano się do strajku generalnego, powołując straż robotnicza; niektórzy proponowali nawet montaż broni palnej. „Wyśmialiśmy ich wtedy...”, wspominał Jerzy Kaniewski ${ }^{6}$, późniejszy przywódca grudniowego strajku. Władze Regionu przenoszą się do Ursusa 7 , 27 marca ma miejsce czterogodzinny strajk ostrzegawczy, na który przybył Lech Wałęsa. Wg materiałów SB przewodniczący Solidarności w Ursusie, Zbigniew Janas, czuł się na tyle pewnie, że już pod koniec 1980 roku mówił premierowi, że „nie uznaje kierowniczej roli Partii na terenie Zakładu”.

Strajkowano 23 października ${ }^{9}$, i 28 (7 tysięcy pracowników) ${ }^{10} .30$ listopada rozpoczęto przygotowania do strajku, który miał się rozpocząć w poniedziałek 14 grudnia albo zaraz po Nowym Roku ${ }^{11}$. Na 15 grudnia planowano referendum w sprawie strajku czynnego, polegającego na uruchomieniu produkcji i dystrybucji pod kierunkiem samorządu i w ścisłej współpracy z Siecią największych w Polsce zakładów produkcyjnych. Wg ocen milicji byłoby to „wyprowadzenie z Ursusa organizacji partyjnej PZPR i przejęcie władzy przez samorząd”. Napięcie rosło.

13 grudnia w warszawskich fabrykach był stosunkowo spokojny - strajków nie podejmowano, była to niedziela ${ }^{12}$. Milicja trzykrotnie rozpędzała jednak ludzi zbierających się pod siedzibą Zarządu Regionu Mazowsze ${ }^{13}$. Wybuchu protestów w fabrykach można się było spodziewać w poniedziałek. Wprowadzenie stanu wojennego musiało wywołać reakcję robotników Ursusa - stąd zrozumiałe zdenerwowanie Lipskiego, który był jednym z członków Zarządu Regionu. Czuł się odpowiedzialny za sytuację, bał się rozlewu krwi.

14 grudnia około szóstej rano w Ursusie na bazie prezydium komisji fabrycznej NSZZ Solidarność powstał komitet strajkowy, na którego czele stanął Jerzy Kaniewski, trzeci w hierarchii zakładowej Solidarności ${ }^{14}$. Przewodniczacy, Zbigniew Janas, był w Gdańsku, zaś wiceprzewodniczący, Wojciech Gilewski, został internowany ${ }^{15}$. Strajk podjęło ok. tysiąc pracowników z I zmiany, z których większość została na II zmianie ${ }^{16}$, która weszła o 14 (jeszcze ich wpuszczono, jak zapamiętał przywódca strajku) ${ }^{17}$. Kiedy liczyli się o 11, było ich ponad 1200 osób ${ }^{18}$. W miarę upływu czasu strajkujący wykruszali się jednak. Kadrowiec rozdał kierownikom plik kart urlopowych ${ }^{19}$. Przywódca strajku wspominał: , «Ursus» to 20 zakładów rozrzuconych na dużym obszarze. Od rana ludzie gromadzili się w głównych halach, u siebie. Ale kiedy zaczęto wydawać karty urlopowe, bardzo wielu z nich skorzystało. Początkowo

001708/3699), k. 6, 45, 46. Wg Sieradzkiego w 1989 r. było to 16340 osób: 6400 pracowników fizycznych i 9940 pracowników umysłowych; I zmiana liczyła 14 026, II zmiana - 1 823, a III - 491 pracowników.

${ }^{5}$ Ibidem, k. 63.

${ }^{6}$ E. Poliński [A. Gelberg], Póki żyjemy..., Warszawa 1986, s. 27. Książka powstała na podstawie relacji usłyszanej przez autora w więzieniu od przywódcy strajku.

${ }^{7}$ B. Sieradzki, Zwalczanie nielegalnej džiałalności..., k. 64.

${ }^{8}$ Ibidem, k. 63. Rozmowa Janasa z Józefem Pińkowskim, podczas której padły te słowa, miała mieć miejsce 18 listopada $1980 \mathrm{r}$.

${ }^{9}$ Chodziło o impas w rozmowach dotyczących zróżnicowania podwyżek płac, przybywa Lech Wałęsa, strajk został przerwany po 3 godzinach. Encyklopedia „Solidarności” wersja internetowa: http://www.encyklopedia-solidarnosci.pl/wiki/index.php? title=TL-1980/10)

${ }^{10}$ Jednogodzinny solidarnościowy strajk ostrzegawczy w Regionie „Mazowsze” popierający strajkujące włókniarki z Żyrardowa. ${ }^{11}$ Inf. M. Srebrny; datę tę potwierdza także B. Sieradzki, Zwalczanie nielegalnej driałalności..., k. 66, pisząc o decyzji Prezydium ZF (praca Sieradzkiego nie może być traktowana jako pewne źródło informacji, obok tej daty pojawia się też bowiem informacja o przygotowywanych przez Solidarność w Ursusie... szubienicach (rozpowszechniona wówczas narracja wśród działaczy PZPR).

${ }^{12}$ Był to jeden z argumentów np. Prezydium Komisji Zakładowej NSZZ „Solidarność” w Hucie Warszawa. Por. T. Ruzikowski, Stan wojenny w Warszawie i w wojewódz̨twie stołecznym 1981-1983, Warszawa 2009, s. 292.

${ }^{13}$ W. Polak, Opór społeczny w pierwssyych dniach stanu wojennego, „Wolność i Solidarność” 2012 nr 3, s. 53-63.

${ }^{14}$ E. Poliński, Póki żyjemy..., s. 6.

15 J. Domżalski, M. Jarosiński, Gdy chcielismy być wolni. URSUS w latach 1980-1989, Warszawa 2010.

${ }_{16}$ B. Sieradzki, Zwalcranie nielegalnej driałalności..., k. 66.

${ }^{17}$ E. Poliński, Póki żyjemy..., s. 6.

${ }_{18}$ Wywiad Grzegorza Kaczorowskiego z Emilem Broniarkiem, 18 kwietnia 2008 (http://www.fundacjakos.pl/projekty/wywi ady/eacea_broniarek_emil.pdf), s. 5 („1250 parę osób”). Wg. szacunków MSW miało strajkować ok. 2 tys. osób, przed interwencją ZOMO już tylko kilkaset (T. Ruzikowski, Stan wojenny w Warszawie..., s. 294 - autor nie podaje jednak źródła, z którego korzystał).

${ }^{19}$ E. Poliński Póki żyjemy..., s. 6. 
ludzie brali i mówili: «To tylko tak, na wszelki wypadek, dla bezpieczeństwa». Z godziny na godzinę było nas jednak coraz mniej, w poszczególnych zakładach i wydziałach zostało po kilkanaście osób. [...]

Zbliżała się noc. [...] Komitet strajkowy kilkanaście razy głosował - wychodzimy czy zostajemy? I zostaliśmy. Czterysta osób z piętnastu tysięcy, bo tyle pracuje w »Ursusie«"20.

Chociaż strajk 14 grudnia planowano jeszcze przed wprowadzeniem stanu wojennego, to w porównaniu z wcześniejszymi akcjami protestacyjnymi uczestniczyło w nim znacznie mniej ludzi, wyczerpanych wielomiesięczną huśtawką pełzającej konfrontacji, przestraszonych konsekwencjami, zapewne bardziej też sceptycznie niż kilka miesięcy wcześniej patrzących na Solidarność. Zmniejszanie się liczby strajkujących mogło prowadzić do radykalizacji poglądów i działań (straż przemysłowa w zakładach posiadała broń palnąa2).

Jan Józef Lipski trafił do Ursusa ok. 14.30, już po wejściu drugiej zmiany, wprowadzony na teren zakładów22. Według jednej z legend miał przyjechać ciężarówką; tymczasem wprowadził go najprawdopodobniej jeden z robotników, Arkadiusz Czerwiński.

Zjawił się w Ursusie w poczuciu solidarności, czując się odpowiedzialny za los robotników - uważał, że jego miejsce, jako członka Prezydium Zarządu Regionu Mazowsze NSZZ Solidarność, jest w jednym ze strajkujących zakładów. 6 stycznia 1982 roku Lipski powie w sądzie, że pojechał tam też motywowany dodatkowo związkiem sentymentalnym - to przecież w reakcji na protest w Radomiu i Ursusie powstał KOR. Przede wszystkim zaś, mówił Lipski, ,jako członek Prezydium NSZZ Solidarność Regionu Mazowsze nie wyobrażałem sobie, że może nie być strajku, bowiem Komisja Krajowa uchwaliła odpowiedzieć strajkiem powszechnym na wprowadzenie stanu wyjątkowego czy wojennego, uważałem więc, że dla mnie, jako członka Prezydium Regionu Mazowsze, miejsce jest w jakimkolwiek zakładzie pracy, gdzie strajkują, i to z dwu powodów: jeśli robotnicy strajkują to moim obowiązkiem i honorem jest być z nimi; ponadto byłem przekonany, że zakłady, w tym i Ursus, będą strajkowały. Sprawą honoru było nie kryć się, lecz jako demokratycznie wybrany członek władz Regionu być z robotnikami.

Nie było wiadomo, co wyniknie; jestem człowiekiem doświadczonym, w tym roku kończę 56 lat, orientowałem się, że mogę tam być potrzebny, że - być może - moja obecność zdoła zapobiec sprawom najgorszym. Przekonałem się, że mam autorytet w Ursusie jako jeden z założycieli KOR-u i postanowiłem ten autorytet wykorzystać" 23 . Lipski przekonywał robotników do stosowania wyłącznie biernego oporu. Nie namawiał ich do poddania się wzywał do zamanifestowania sprzeciwu, ale bez przelewu krwi. Podobnie mówił przywódca strajku, Kaniewski.

W roku 1987 Lipski napisze: „,...] tłumaczyłem w grudniu 1981 roku robotnikom w otoczonej przez czołgi fabryce traktorów „Ursus”, że nie możemy podjąć walki, gdy zacznie szturm ZOMO do naszych fabrycznych hal. Znalazłem się tam z poczucia obowiązku - nie należałem do załogi, byłem docentem w Instytucie Badań Literackich, lecz zarazem członkiem regionalnego NSZZ „Solidarność”. Gdzie wówczas, po wprowadzeniu stanu wojennego, było moje miejsce, jak nie wśród strajkujących robotników"24.

W „Ursusie” był też wówczas m.in. Marian Srebrny, związany z zakładową Solidarnością (prowadził Wszechnicę Robotniczą Solidarności) ${ }^{25}$. Zaproponował zorganizowanie wykładów - razem z Lipskim nazywają to Wszechnicą Strajkową Solidarności; pierwszy wykład, o 20, miał wygłosić właśnie Jan Józef.

Około siedemnastej zakłady zostały otoczone brygadą ZOMO26, wzdłuż ulicy ustawiły się Bojowe Wozy Piechoty (BWP) i kolumna samochodów ciężarowych z 13 pułku zmechanizowanego z Kożuchowa. „Krążyły słuchy,

\footnotetext{
${ }^{20}$ Ibidem, s. 6, 7.

${ }^{21} 111$ osób i 7 pracowników pomocniczych, dysponujących 33 sztukami pistoletów WZ i 4 sztukami PM (tj. zapewne pistoletów Makarowa) - to prawdopodobnie dane z roku 1989. B. Sieradzki, Zwalçanie nielegalnej dzৃiałalności..., k. 47.

${ }^{22}$ Lipski nie mógł być, o co go oskarżano, w Ursusie rano, skoro Michał Głowiński zapamiętał go przed południem w IBLu; Lipski przed sądem wymieniał właśnie godzinę „ok. 14.30”. Por. AIPN, 960/1336, k. 52.

23 AIPN, 960/1336, k. 52.

${ }^{24}$ Tekst napisany do „eseju fotograficznego” Pamię́ murów 1987-1944 Grzegorza Nawrockiego (późniejszy tytuł: Mury mówia); wystawa (otwarta właśnie przez Lipskiego) prezentowana była w parafii Miłosierdzia Bożego w Warszawie w grudniu 1987 i styczniu 1988. J.J. Lipski, Pamiéć murów. Warszawa 1987 - 1944 [w:] idem, Pisma polityczne. Wybór, oprac. L. Garbal, Warszawa 2011, s. 339.

25 Por. M. Srebrny, Strajk 14 grudnia 1981 roku - wspomnienia Mariana Srebrnego, [w:] J.Domżalski, M.Jarosiński, Gdy chcielismy być wolni. Ursus w latach 1980-1989, Warszawa 2010.

${ }^{26}$ E. Poliński [A. Gelberg], Póki żyjemy..., s. 6.
} 
że załatwili już FSO i Hutę. Teraz przyszła kolej na nas”, wspominał Kaniewski. W rzeczywistości strajk w Hucie Warszawa zostanie rozbity po północy 15 grudnia 27 , w FSO zaś noc później28. Strajkujący próbowali porozumieć się z dowódca, jednak otaczający zażądali bezwarunkowego opuszczenia zakładu²9.

Ówczesny dowódca jednego z plutonów 13 pułku, młody podporucznik świeżo po szkole oficerskiejº, wspomina, że była to dla żołnierzy trudna sytuacja; sami mieli krewnych w Solidarności. Nie czuli zagrożenia ze strony strajkujących, nie byli też wrogo nastawieni. Nie wydano im ostrej amunicji. Nie mieli też kontaktu z oddziałami, które pacyfikowały zakłady. Mieli jedynie blokować - i, w zależności od rozkazów, wpuszczać ale nie wypuszczać pracowników (później zaś na odwrót: nie wpuszczać, ale wypuszczać).

Protestujący nie mieli wystarczających sił do okupowania całego terenu zakładów, pod wieczór przenieśli się do świetlicy. „Zbliżała się noc. Oni wzdłuż parkanu, my w świetlicy, jakieś trzysta, czterysta metrów od nich. Taka Reduta Ordona z czterystu ludzi. Komitet strajkowy kilkanaście razy głosował - wychodzimy czy zostajemy? I zostaliśmy"31.

Przed planowaną godziną wykładu Lipskiego o dwudziestej „poszła plotka, że będzie szturm”32. Lipski poszedł na obrady Komitetu Strajkowego. Srebrny pamięta, że zrobił się ,jakiś tumult [...] obradowali jakby na scenie, za jakaś kurtyną. Co jakiś czas Lipski wychodził na chwilę zza tej kurtyny. Rozmawiał z ludźmi, dodawał im otuchy. Był człowiekiem, który nigdy nie przemawiał, on tylko rozmawiał. Miał niezwykły dar rozmawiania”.

W zakładzie zjawił się Wiktor Kulerski333, wiceprzewodniczacy Zarządu Regionu, nauczyciel biologii i historii. Tak wspomina swoje spotkanie z Lipskim: „Skąd się tu wziąłeś? - zapytałem. On uściskał mnie i ciepło powiedział: - Ja potrafię tylko pisać, a teraz moje miejsce jest tutaj, wśród robotników.

- Ale ja, Janie Józefie, co ja mam zrobić?

- Wkroczą tu i szybko nas pokonają. Jeśli sądzisz, że wszystko stracone, możesz z nami zostać, lecz jeśli uważasz inaczej, powinieneś stąd odejść, i to jak najszybciej.

Uścisnęliśmy się bez słowa" 34 .

Padła wtedy propozycja, że z działaczy zostanie tylko dwóch (Broniarek i Tadeusz Wypych?), a reszta ma wyjść. Broniarek protestował, Lipski kazał wyjść właśnie jemu, mówiąc, że jest umówiony z korespondentami zachodnimi w „Bazyliszku” na Starym Mieście ${ }^{35}$, zapewne prosząc go o spotkanie z nimi.

Około północy część ludzi poszła do narzędziowni36. Słyszą warkot silników, zamykają się za metalowymi drzwiami - ale tylko na mały miedziany drucik. „Wpadliśmy na halę i takiego chłopaka pytam: »Macie tę kłódę, żeby zamknąć te metalowe drzwi?», a on mi, pamiętam jak dziś - mówił jeden ze strajkujących - taki miedziany drucik dał. Mówię: «Rany boskie, ludzie, my do niczego nie [jesteśmy] przygotowani«”37.

\footnotetext{
27 Wypowiedź E. Mizikowskiego, „1” (biuletyn ArcelorMittal Warszawa), 2012, nr 16.

28 A. Paczkowski, podaje godz. 22.30. Zob. idem, Wojna polsko-jaruzelska. Stan wojenny w Polsce 13 XII $1981-22$ VII 1983 , Warszawa 2007, s. 86.

${ }^{29}$ Starszym oficerem operacyjnym w sztabie 13 Pułku Zmechanizowanego 5 Dywizji Pancernej był wówczas kapitan (lub jeszcze porucznik) Marek Samarcew, ur. 1951 r. (por. M. Jędrzejko, M.L. Krogulski, M. Paszkowski, Generatowie $i$ admirałowie III Rzecsypospolitej: 1989-2002, Warszawa 2002, s. 267 ). Samarcew jest obecnie członkiem rady nadzorczej jednej z firm deweloperskich - JW Construction; mimo wielokrotnych prób nie udało mi się z nim bezpośrednio skontaktować. Dowódca pułku był wówczas podpułkownik Zdzisław Wijas (ibidem, s. 310), niestety nie udało mi się go odnaleźć.

30 Zbigniew Smok, ur. 1957, dzisiaj generał brygady, szef sztabu i zastępca dowódcy 1 Dywizji Kawalerii Pancernej.

${ }^{31}$ Ibidem, s. 6.

${ }^{32}$ M. Srebrny, Strajk 14 grudnia...

${ }^{33}$ Por. W. Kulerski, Bardzo dtugi spacer zpsem, „,Wolność i Solidarność” 2012 nr 3, s. 180-195. Wspomina on, że do Ursusa chciał jechać już w nocy 13/14 grudnia, trafił jednak wtedy do dyspozytorni taksówkarzy. Dzień później, 14 grudnia, najpierw próbował dostać się do Huty Warszawa; po niepowodzeniu pojechał do Ursusa.

${ }_{34}$ W. Kulerski, Bardzo dtugi spacer zpsem..., s. 182. Kulerski po wyjściu ukrywał się m.in. na parafii ks. Zawitkowskiego, razem z Janasem (notabene swoim byłym uczniem), a później z Bujakiem.

35 Ibidem, s. 7.

${ }^{36}$ Wywiad z. Emilem Broniarkiem, s. 6.

${ }^{37}$ Ibidem, s. 6. Wojciech Polak pisze o ataku sił ZOMO kilka minut przed północa. Zob. W. Polak, Opór spoteczny w pierwssych dniach stanu wojennego..., s. 58.
} 
W innych fabrykach praktykowano wówczas spawanie wierzei bram wjazdowych, zastawianie terenu za nimi ciężkim sprzętem, itp. ${ }^{38}$ - jak wynika z tej relacji Ursus nie był przygotowany do długotrwałego oporu. Jeździły czujki na motocyklach ${ }^{39}$, Jerzy Kaniewski myślał o robieniu „koktajli Mołotowa”. Opowiadał później w więzieniu: „o pierwszej w nocy czujki doniosły, że ruszyli. Mieliśmy zaledwie parę minut, by przejść ze świetlicy na halę. Było nas ze czterystu. Stanęliśmy w kole. Wcześniej postanowiliśmy, że zachowujemy się spokojnie. Strajkujemy, ale nie walczymy.

Wdarli się przez okna. Brama jednak nie puściła i te siekierki z widłowymi ostrzami musieli sobie stępić. Było ich ze trzydziestu, czterdziestu, na początek. Brodaci, nawet nie tacy rośli, ale od razu widać, że specjalnie szkoleni. Ubrani różnie i różnie uzbrojeni. Jedni z «rakami», inni z «kałasznikami», jeszcze inni z nożami, wygląd raczej bandycki”"40.

Lipski wspominał: „gdy wywalono bramę i wkroczyła na halę brygada antyterrorystyczna, wymierzając w nasze brzuchy broń, okazało się, że jest nas tylko czterystu. Największych krzykaczy obok siebie nie zauważyłem”"41.

Broniarek pamięta, że „bramę atakowali ludzie pana Dziewulskiego. Pan Dziewulski wpadł do hali z tymi swoimi, ja to nazywam, zbirami. Było mi bardzo wesoło, bo nie mogli wejść przez ten drucik. Jak by się który dobrze zaparł, to by to wypchnął. Oni musieli przy zamknięciu jakiś ładunek [podłożyć], bo dziurę wywalili. To było dla mnie żenujące"42.

Według mojej rozmowy z Jerzym Dziewulskim (dowódca oddziału antyterrorystycznego na warszawskim lotnisku Okęcie, po 1989 r. m.in. doradca prezydenta Kwaśniewskiego i poseł) była to jego jednostka z komendy milicji Centralnego Portu Lotniczego Okęcie, oraz Wydział Zabezpieczenia Komendy Stołecznej MO majora Edwarda Misztala ${ }^{43}$. Dziewulski do dziś doskonale pamięta ten dzień, ponieważ miał wówczas urodziny i liczył, że uda mu się pojechać normalnie do domu; tymczasem nakazano mu poderwać swoich ludzi i pojechać z lotniska do zakładów Ursusa. Na pytania o cel akcji usłyszał, że mają otworzyć zamknięte drzwi; wsparcie zapewni otaczająca zakłady dywizja pancerna plus jednostka Misztala. Jechali UAZ-ami, około kilometr przed zakładami zaczął ich - na prośbę Dziewulskiego - pilotować radiowóz.

Zapamiętał czołgi i transportery przed brama - zapewne nie wjechały na teren zakładów. Od młodego funkcjonariusza SB w cywilnym ubraniu usłyszał, że mają otworzyć bramę. - Ale dlaczego - miał pytać. - Tam są strajkujący, usłyszał. Pytał dalej o możliwe zagrożenie; funkcjonariusz SB sprawiał wrażenie, że nie wie, czy jakieś istnieje, czy strajkujący maja broń - ale nie chciał tego przyznać wprost. To była sytuacja niebezpieczna; funkcjonariusz SB straszył dodatkowo Dziewulskiego możliwą agresją strajkujących. Mówił, żeby uważali, próbując otworzyć bramę, bo „obetną wam rękę”. „Trochę pierdoły” - dziś mówi Dziewulski, który zapytał go, skąd o tym wie, i czy mają broń. Sam zakładał, że strajkujący raczej nie są agresywni, w tych dniach widział raczej strach i bierność po stronie protestujących, niż agresję (nawet w pacyfikowanej przez jego oddział przed wprowadzeniem stanu wojennego szkole pożarnictwa) - tak też miał powiedzieć swoim ludziom.

Wg Dziewulskiego do otwarcia wielkich metalowych drzwi (mniej więcej 3 metry na 3) nie użyli materiału wybuchowego, tylko toporów. Wycięli otwór. Dziewulski pamięta włożony między skoble pręt („może duży gwóźdź, nie pamiętam"), który jeden z jego ludzi wysunął. Wchodzą, uzbrojeni w pistolety maszynowe typu PM63 „Rak” kalibru 9 mm, lekkimi, o wielkim natężeniu ognia. Sam Dziewulski (wówczas kapitan) mówi, że miał broń osobista, oraz, że wszyscy mieli na sobie hełmy spadochronowe z goglami, zasłaniajacymi twarze (inaczej to pamięta Marian Srebrny, inaczej też opisał to Jan Józef Lipski $\left.{ }^{44}\right)$. Dziewulski wspomina, że było ich około czterdziestu.

\footnotetext{
38 A. Paczkowski, Wojna..., s. 82.

${ }^{39}$ Wywiad z Jerzym Kaniewskim przeprowadzony przez Marię Bal w Warszawie, dn. 21 grudnia 2007 roku (http://www.fundacjakos.pl/projekty/wywiady/fio_kaniewski_jerzy\%27.pdf) (Projekt 233/2007. Ocalmy od zapomnienia - relacje represjonowanych w stanie wojennym).

${ }^{40}$ E. Poliński, Póki żyjemy..., s. 5.

${ }^{41}$ J.J. Lipski, Wyznania, przygotowała i oprac. M.D. Pieńkowska ...

42 Wywiad z Emilem Broniarkiem, s. 6.

${ }^{43}$ Rozmowa z Jerzym Dziewulskim, 27 czerwca 2013 r.

${ }^{44} \mathrm{Wg}$ Mariana Srebrnego potwierdzą to także Emil Broniarek, Roman Bielański, Alicja Szot.
} 
Lipski w roku 1987 wspominał: „w 1944 roku może co dwudziesty z nas miał broń palną, prawie każdy butelkę zapalającą czy granat... Ci, co wtargnęli na halę fabryczną byli uzbrojeni: każdy z pistoletem maszynowym w dłoni, a z każdego ich ruchu, ze zręczności, z jaką na wszelki wypadek szukali osłony za maszynami - widać było, że są dobrze wyszkoleni. Ja, żołnierz powstania, mogłem to ocenić” 45 .

Przywódca strajku Jerzy Kaniewski: „Major, który nimi dowodził, wskoczył na jakaś hałdę i powiedział, żebyśmy się nie ruszali, bo oni nie chca z nami walczyć. Przyszli, żeby nas tylko spacyfikować i jak nie zaczniemy, wszystko odbędzie się spokojnie.

Jednak był zdenerwowany i jego ludzie też. Robili takie dziwne ruchy, skłony, przysiady. Potem, w więzieniu, gdy przypominałem sobie tę scenę, wydawała mi się nawet śmieszna. Ale nie wtedy.

Stałem obok młodego chłopaka, chyba jeszcze przed wojskiem. Nogi w kolanach tak mu dygotały, że nie mógł ustać i musiałem go podtrzymywać. Nie można jednak powiedzieć, że był tchórzem, bo przecież został. Wiedział, co jest grane... i został. Tylko te nogi mu tak chodziły..." ${ }^{46}$

Emil Broniarek zapamiętał, że dowódca „stał na pojemniku z takimi śrubami, gdzie mu się noga mogła obsunąć"; używane przez pacyfikujących pistolety maszynowe cechowały się zaś łatwością przypadkowego wystrzału jednak obyło się bez strzelaniny.

„Ich przyjechało ze 100, 20 weszło na salę - wspominał Kaniewski w 2007 r. - Czuli się niepewnie, ale to jakiś oddział, w panterkę, wskoczyli z jakimiś tam uzi czy kałasznikowami. Ale nie było walki. Oni się chyba więcej bali, niż my, że się zacznie" 47 .

Srebrny oceniał ich liczbę na ok. 50 osób. Wspominał też, że kiedy ich okrążali Arkadiusz Czerwiński „podszedł do Jana Józefa Lipskiego i powiedział: Weźmiemy pana profesora w środek"'(robotnicy własnymi ciałami zasłonili też Srebrnego).

Dowódca oddziału krzyknął, żeby wyciąnęli ręce z kieszeni, bo nie chce do nich strzelać: „teraz wiem, że mieli ostrą amunicję - wspomina Broniarek. - Wycelowano w nas. U nas ta grupka ludzi zaczęła śpiewać Hymn, to ja krzyknąłem, że nie śpiewamy. Ta grupka ruszyła, zacząłem być wypychany w ich stronę. Krzyknąłem, bo jeszcze pół godziny przed pacyfikacją drukowałem na powielaczu pismo Krupińskiego na papierze pakowym, że to ma być bierny strajk, mamy nie atakować. I ja się tego trzymałem, że po prostu biernie stoimy. Zatrzymują nas, to nas zatrzymują, nie robimy awantury. Ale pamiętam, jak skończyłem drukować, to poszedłem do takich chłopaków, poprosiłem ich, żeby schowali tę maszynę. Mówię: „A ja do was dotrę, wy się nie przejmujcie; jak ja będę bardzo chciał, to was znajdę, bo ja nie chcę wiedzieć, gdzie to jest.”. Zabezpieczałem się [na wypadek] aresztowania. Miałem wyłamane drzwi (tylko ja i Jan Józef Lipski na tym strajku mieliśmy wyłamane drzwi)”.

Dziewulski przedstawia sytuację nieco inaczej. Opisuje kontrast między tym, czego się spodziewał - a jeszcze bardziej między sytuacją prognozowana przez funkcjonariusza SB po cywilu - a tym, co zastał. Pamięta gigantyczną halę, ludzi stojących w zbitej grupce (jak twierdzi, zapamiętał ich znacznie mniej, niż w innych relacjach, 20-50 osób), około 20 metrów od otwartych drzwi, stojących na porozrzucanych podestach-paletach. I ogromne ilości wody. Strajkujący potwornie wystraszeni, zmęczeni. Spokojni, skupieni. Dziewulski - jak twierdzi - w okularach i hełmach podchodzi ze swoimi ludźmi jakieś 10 metrów; z tyłu słyszy głos jednego ze swoich: „kurwa mać, szefie, co my tu robimy”. Wspomina, że dał komendę „panowie, w tył zwrot, wychodzimy stąd”; razem z nimi wycofali się ludzie Misztala. Do hali weszli zomowcy.

Dziewulski spojrzał na funkcjonariusza SB w cywilu, pokiwał głowa, i powiedział „macie takie rozpoznanie jak Kowalski...”. Wyszli, wspomina, „skonfundowani, wkurwieni; antyterroryści, a tam taka nędza, bida robotników, przerażonych, w wodzie, w smrodzie smarów...”.

Pluton specjalny Komisariatu Milicji MDL Okęcie pod komendą Dziewulskiego wszedł (siła) tylko do jednej z dwóch zajmowanych przez strajkujących hal. Część ludzi została na innej hali48. Przywódca strajku wspominał: „[...] gdy dowódca grupy antyterrorystycznej zobaczył, że walki nie będzie, to krzyknął i do hali weszli zomowcy

45 J.J. Lipski, Pamięć murów....

46 E. Poliński, Póki żyjemy..., s. 5.

${ }^{47}$ Wywiad z.Jeraym Kaniewskim...

${ }^{48}$ Wymiad z. Emilem Broniarkiem, s. 6. 
w normalnym oporządzeniu, z tarczami, pałami i przyłbicami. Utworzyli »korytarz«, przez który kazano nam przechodzić. Bicia nie było.

W pewnym miejscu »korytarza«»była bramka«. Stał tam pułkownik z kilkoma esbekami i wybierali ludzi. Podchodziło dwóch, brało pod ręce i prowadziło, a częściej wlokło przed halę. Tych nieodłączonych puścili do domu"49.

Według Broniarka „selekcji” dokonywał dowódca szturmujących (którego utożsamia z Dziewulskim), razem „z takim policjantem zakładowym, panem Szczepanikiem”. Można było jednak próbować uciec, jak dalej wspomina Broniarek, który powiedział do żony Bujaka: „„Słuchaj, Wacka, idź tam z drugiej strony, bo ja nie będę szedł tutaj, ja idę na tych pałkarzy, co tak strasznie wala. Tam po grzbiecie - mówię - dostanę i mnie wyrzucą, bo muszę wyjść. Jan Józef Lipski kazał"”50.

Niektórym innym też udało się ukryć - np. Wiktorowi Kulerskiemu czy Czesławowi Latuskowi (przedostał się na plebanię rzymskokatolicką w Gołąbkach - proboszczem był tam wówczas ks. Józef Zawitkowski, obecny biskup pomocniczy diecezji łowickiej).

Kaniewski zapamiętał, że pacyfikujący „mieli jakaśs wtykę, bo wyłuskali Jana Józefa Lipskiego, ale był również spory bałagan, bo całego komitetu strajkowego nie wygarnęli. Przed hala stał reflektor lotniczy i walił prosto w oczy. A obok, trochę z lewej strony, stanowisko karabinu maszynowego. Postawiono nas przed tym karabinem. I staliśmy tak z kilka minut...." ${ }^{1}$.

Była zimna grudniowa ciemna noc (w dokumentacji zapisano, że Lipskiego zatrzymano o 2.10 po północy52). Broniarek, którego przepuścili razem z mama, po czym udało mu się przejść przez kordon i uciec, zapamiętał, że „od wyjścia do tunelu stali jacyś młodzi żołnierze, takie dopiero co powołane młode roczniki. Niektórym łzy widziałem [płynęły]. Utkwiły mi [w pamięci] takie grube płaty śniegu i dwa pociagi podstawione na stacji”.

Zatrzymany Kaniewski widział sytuację z innej perspektywy: „podjechały dwie suki” [,suką” nazywano zamkniętą ciężarówkę milicyjna - przyp. $L G]$ i załadowano nas. W samochodach było zimno jak cholera, wszyscy dygotali. Gadać nie było o czym i każdy dochodził do siebie po tym staniu pod lufa”".

Lipski zdą̇ył jeszcze powiedzieć swoim kolegom o przysługujących im prawach ${ }^{53}$ - koncentrował się zapewne na podkreśleniu prawa do odmowy zeznań.

Zatrzymanych przewieziono na komendę MO przy Opaczewskiej54 (Kaniewski mówił o ulicy Banacha, to zapewne pomyłka - Opaczewska jest obok Banacha). Tam czekała na nich „ścieżka zdrowia” - szpaler milicjantów (nie zomowców) z uniesionymi pałkami, zmuszając do biegu do drzwi, schodami na pierwsze piętro, i korytarzem do końca. Tu też nie bili, tylko straszyli. Sześćdziesięciu zatrzymanych zgrupowano w świetlicy. Jeden z pilnujących ich - płakał. „Później dowiedziałem się, że tym esbekom powiedziano, że wiozą bojówki, które szykowały się do wieszania, mordowania, wojny domowej. I że nad ranem mają nas wszystkich rozwalić... A my wyglądaliśmy nieszczególnie. Wymarznięci, zmęczeni, brudni, wielu w ubraniach roboczych, kobiety w kufajkach”55.

Zatrzymanych rewidowano, po czym rozlokowano w dwóch wielkich celach („tygrysówach” - z krata zamiast jednej ze ścian, cały czas na widoku). „Straszliwa ciasnota [...] co najmniej połowa z braku miejsca musiała stać. Robiliśmy zmiany. Wiele z tej nocy nie pamiętam, po prostu uszło ze mnie powietrze. Zmęczenie... Przez całą noc brano ludzi na przesłuchania. [...]".

Przesłuchujący odbiegali od stereotypu „prostego esbeka”; wyszkoleni psychologicznie, nie podsuwali niczego do podpisywania, starali się raczej sprawić, że zatrzymani sami zaczną mówić, cokolwiek - Kaniewskiemu mówiono na przykład, że będzie tylko świadkiem ${ }^{56}$. Mówili „krótko, oni już wszystko wiedzieli”.

\footnotetext{
${ }^{49}$ E. Poliński, Póki żyjemy..., s. 7.

${ }^{50}$ Wywiad z Emilem Broniarkiem, s. 7.

${ }^{51}$ E. Poliński, Póki àyjemy..., s. 7.

52 AIPN 481/49/CD/1, k. 10.

53 Por. AIPN, 960/1336, k. 52.

${ }^{54}$ List Marii Lipskiej do Prymasa Glempa z 28 grudnia 1981 r., Archiwum domowe Jana Józefa Lipskiego - dalej: AD JJL, poz. 1475.

${ }^{55}$ E. Poliński, Póki żyjemy..., s. 8.

${ }^{56}$ Ibidem, s. 9.
} 
W roku 2007 Kaniewski wspominał: „to tak jak Lipski napisał w jakiejś książce, za dużo żeśmy powiedzieli. Bo każdy z nas się przyznał. Trudno było się nie przyznać, wydawało nam się, że głupio było się nie przyznać do tego, co żeśmy tam robili. On to później źle ocenił, nawet mam tam gdzieś jego wycinek, jako że uważał, że źle żeśmy zrobili przyznając się, bo oni na tej podstawie nas skazali. A tak to by musieli znaleźć jakiś świadków. A myśmy działali jawnie, wydawało nam się głupotą nie przyznawać się do tego. A to jeszcze był taki czas, że: a dlaczego ja mam się wstydzić tego, co robiłem" 57 .

Faktycznie, Lipski w wywiadzie dla konspiracyjnej gazetki „Ursusa” w 1987 r. dokonał oceny strajku w „Ursusie”, mówiąc: „podczas powstania [warszawskiego - przyp. $\ell G]$ przekonałem się, jak małe szanse mają ludzie słabo uzbrojeni. W „Ursusie” było to samo. Ludzie, którzy mogli uzbroić się w łomy, mieli szansę tylko ginąć. Uważałem, że trzeba zrobić wszystko, aby tych ludzi oszczędzić. Nie warto było, aby „Ursus” przeszedł do historii dlatego, że zginęło w nim kilku czy kilkudziesięciu robotników. Natomiast namawiałem do oporu biernego. Strajk powinien być, gdyż mieliśmy prawo do protestu. Podkreślałem jednak: nasza obrona powinna być bierna.

Inna rzecz, że na biernej obronie zawiodłem się. Nie tylko dlatego, że na strajku zostało mało ludzi, ale również dlatego, że tak niewielu wzięło sobie do serca moje wskazówki już potem, gdy przewieziono nas na Opaczewska. Trzeba było na przesłuchaniach milczeć.

Wielu paplało, ci najszlachetniejsi obciążali siebie. A przecież i tak dostarczali informacji przeciwnikowi”58.

Jerzy Kaniewski zwracał jednak uwagę na inny aspekt tej sytuacji. Mówił w więzieniu, że, mimo faktu, iż każdy z nich znał broszurę Obywatel a Stużba Bezpieczeństwa, mimo wiedzy, że w obliczu przesłuchującego najlepiej odmawiać zeznań - ich zachowanie motywowane było przynależnością do Związku, który oficjalnie był uznany za legalny ${ }^{59}$.

W wyniku pacyfikacji w „Ursusie” milicja zatrzymała i przewiozła na Opaczewską około 60 osób. Większość z tej sześćdziesiątki puszczono potem do domów, aresztowano dziewięciu ${ }^{60}$. Zapewne między 17 a 19 grudnia przewieziono ich do aresztu śledczego na Rakowiecką (nakaz przyjęcia Lipskiego datowany był właśnie na 16 grudnia ${ }^{61}$, z kolei Kaniewski pisał o przewiezieniu go na Rakowiecką 19 grudnia; wówczas też dopiero oddali mu okulary) Prokuratura („,cywilna” - pod postanowieniem o tymczasowym aresztowaniem Lipskiego podpisany jest Prokurator Rejonowy dla Dzielnicy Warszawa Ochota, Zygmunt Zwolak) wszczyna sprawę o numerze Ds.3414/81.

\section{Przygotowania do procesu}

SB zapewne wiedziała wcześniej o obecności Lipskiego wśród strajkujących, ponieważ został spośród nich „wyłuskany"; postanowienie o jego tymczasowym aresztowaniu było datowane już na 16 grudnia, czyli zapadło zapewne jako jedno z pierwszych, być może jeszcze przed „rozmowami” na Opaczewskiej. Miały one zapewne spełniać rolę „sita”; w przypadku Lipskiego władze nie mogły mieć złudzeń. (Kaniewski wspominał w rozmowie z Gelbergiem, że sankcję dostał tuż przed upływem przepisowych 48 godzin, o północy z 16 na 17 grudnia).

Organa ścigania oskarżyły Lipskiego „o nieprzestrzeganie dekretu z dnia 13.XII.1981 r. tj. o czyn przewidziany w 46 pkt. 1 i 2 dekretu [...]”62; tym samym „został zastosowany” przeciwko niemu ,środek zapobiegawczy w postaci tymczasowego aresztowania [...] z uwagi na to, że sprawa prowadzona jest w postępowaniu doraźnym oraz znaczny stopień społecznego niebezpieczeństwa czynu".

Pismo to - wraz z ocenzurowaną krótką wiadomością od Lipskiego - przekazano do mieszkania Lipskich. Pisał do żony: „Kochana Myszko! W związku z czekającą mnie ewentualnie sprawą w związku ze strajkiem ursuskim

\footnotetext{
${ }^{57}$ Wywiad zJeraym Kaniewskim...

58 J. Domżalski, Polskie sierpnie. WGU rozmawia z Janem Józefem Lipskim, „Wolny Głos Ursusa” 1987, nr 105.

${ }^{59}$ E. Poliński, Póki żyjemy..., s. 10.

${ }^{60}$ W. Polak, Opór społeczny..., s. 56; sierż. B. Sieradzki, Zwalczanie nielegalnej działalności..., k. 67, podaje inne liczby: 11 działaczy „Solidarności” oraz „osoby nie będące pracownikami ZM «Ursus»” (tu brak liczby), 5 działaczy „Solidarności” internowano (zapewne z owej jedenastki). Kaniewski w swojej relacji Gelbergowi wspominał o dziesięciu.

${ }^{61}$ AIPN 481/49/CD/1, k. 8.

${ }^{62}$ AD JJL, poz. 1475.
} 
proszę Ci[e] daj pełnomocnictwa Janowi Olszewskiemu. Całuję Jaś / 16 XII 81 Jan Józef Lipski’”33. Była to pierwsza wiadomość, jaka dotarła do Marii Lipskiej o losach męża. Została ona sama - mąż był w areszcie, syn internowany.

Maria Lipska natychmiast rozpoczęła starania o uwolnienie męża, powiadomiła też o zatrzymaniu Lipskiego jego miejsce pracy, czyli Instytut Badań Literackich PAN ${ }^{64}$ (do którego trafiła też informacja z prokuratury rejonowej ${ }^{65}$ ) i zwróciła się o zaświadczenie lekarskie do doktora leczącego Lipskiego na serce w Londynie.

Sprawa miała toczyć się w trybie doraźnym i to przed sądem wojskowym - na mocy ustawodawstwa bliżej jeszcze nieznanego, z groźnie jednak brzmiącymi paragrafami. Pod postanowieniem o tymczasowym aresztowaniu Lipskiego podpisał się prokurator rejonowy Zygmunt Zwolak ${ }^{66}$. Z tego samego artykułu dekretu z 13 grudnia (przy czym odręcznie poprawiono datę z 12...) oskarżony został m.in. Arkadiusz Czerwiński67.

18 i 19 grudnia grono tymczasowo aresztowanych powiększyło się, ale później zostanie ich już tylko piątka: Jerzy Kaniewski, Arkadiusz Czerwiński, Benedykt Filoda, Witold Ryszard Kaszuba, Jan Józef Lipski68 (być może był także Marian Okipn[y?] ${ }^{69}$. Marian Srebrny wspomina, że cały czas odmawiał zeznań, został internowany, z uzasadnieniem „organizator strajku w Ursusie, czego nie udało się udokumentować procesowo”.

W nocy 18/19 grudnia Lipski doznał w areszcie zawału serca. „Nawet szybko go zabrali i już do nas nie wrócił - wspominał Kaniewski. - Później dowiedziałem się, że żyje i jest w szpitalu więziennym”70. „Oni tam siedzieli na Opaczewskiej w czterdziestu czy iluś w jednej sali - wspominała młodsza siostra Lipskiego. - Oczywiście tam była jedna ławeczka, i to przy kracie, tak że szybko ci ludzie z zakładu go tam posadzili, żeby był w stronę kraty twarza zwrócony, ale tam dostał stanu przedzawałowego. I potem to gorączkowanie, nabawił się przy spadku odporności infekcji, jak taka infekcja idzie przewlekła, to idzie na zastawki..."

Lipskiego przewieziono najpierw do kliniki Akademii Medycznej na ul. Lindleya, gdzie umieszczono go na oddziale reanimacyjnym. „Stwierdzono ostrą niewydolność wieńcową i prawdopodobny zawał. Lekarze uznali za niezbędną hospitalizację co najmniej przez 3 tygodnie. Powiedzieli mi to 23 XII - pisała Maria Lipska do Prymasa Glempa. - Nazajutrz, w dzień Wigilii mąż wprost z sali reanimacyjnej został zabrany do więzienia"71. 24 grudnia, w Wigilię Bożego Narodzenia, Lipski trafił zatem z Ursusa - przez komisariat na Opaczewskiej i szpital na Lindleya - pod dobrze mu znany adres: areszt śledczy Warszawa-Mokotów, Rakowiecka 37.

W areszcie miał być odizolowany od Arkadiusza Czerwińskiego, Mariana Srebrnego, [Mariana Jerzego?] Okipn[ego?], i Jerzego Kaniewskiego. Charakter zatrzymania Srebrnego i Okipnego został zmieniony - zostali internowani w obozie w Białołęce, wyłączono ich więc z potencjalnego procesu.

Proces przeciwko „piątce” z „Ursusa”, uznanej za przywódców strajku rozpoczął się bardzo szybko, bo już na początku stycznia 1982 r. To, prowadzony w trybie doraźnym, proces o charakterze politycznym. Trudno zrozumieć choćby fakt oskarżania „piątki” za to samo, co 30 i 31 grudnia podprokurator (wcześniej podpisywany jako prokurator) rejonowy Zwolak uznał w jednym z przypadków za działanie „usprawiedliwione pobudkami oskarżonego”, i, uzasadniając tym, że „stopień społecznego niebezpieczeństwa zarzucanego [...] czynu nie jest szczególnie wysoki”, zwolnił z aresztu czwórkę innych strajkujących z „Ursusa”, zapewne obejmując ich jedynie dozorem milicyjnym. Te same czyny w procesie ursuskim przedstawione zostaną w sposób zupełnie odwrotny, przynosząc wieloletnie kary więzienia.

63 AD JJL, poz. 1475.

${ }^{64}$ Notatki Marii Lipskiej (dwie karty A4, rkps.) w związku z podjętymi działaniami po aresztowaniu JJL, datowane 16 grudnia , AD JJL, poz. 1475.

65 Instytut Badań Literackich Polskiej Akademii Nauk, Dział Kadr, 519/82 (teczka osobowa Jana Józefa Lipskiego).

66 AIPN 481/49/CD/1, k. 8-9.

${ }^{67}$ AIPN, 754/258.

${ }^{68}$ Według dokumentacji zachowanej w archiwum 30 i 31 grudnia 1981 r. z aresztu na Rakowieckiej zwolniono tymczasowo aresztowanych - z jednym wyjątkiem - 18 grudnia: Witolda Kieliszczyka, Waldemara Woźniaka, Józefa Tomczaka (tymczasowo aresztowanego później od innych - 21 grudnia), Henryka Broniewicza - por. AIPN, 480/3; AIPN, 480/6; AIPN, 480/5; AIPN, 480/1.

${ }^{69}$ AIPN 481/49/CD/1, k. 9.

70 Wywiad z Jerzym Kaniewskim... Datowanie za listem Marii Lipskiej do Prymasa Glempa z 28 grudnia 1981 r., AD JJL, poz. 1475.

${ }^{71}$ List Marii Lipskiej do Prymasa Glempa z 28 grudnia 1981 r., AD JJL, poz. 1475. 
Szczególnie zagrożony był Lipski, wobec którego władza miała zarzuty od lat kilkunastu, a nawet kilkudziesięciu (pierwszy raz przesłuchiwany był w 1953 r., w 1958 r. z powodów politycznych zwolniono go z pracy). Niechęć władz wobec Lipskiego nasiliła się po protestach konstytucyjnych w 1975 roku, w których Lipski grał ważną rolę, szczególnie zaś po powstaniu KOR. Od lipca 1977 r. toczyło się śledztwo z art. 270 par 1 KK (tj. „w sprawie publicznego lżenia, wyszydzania i poniżania Narodu Polskiego, Polskiej Rzeczpospolitej Ludowej, jej ustroju i naczelnych organów"); w tym kontekście dla Lipskiego niebezpieczny był nie tylko udział w strajku, ale także wcześniejsza aktywność publicystyczna, a szczególnie rozgłos eseju Dwie ojçyzny, dwa patriotyzmy. Od czasu publikacji tego eseju latem 1981 r., a szczególnie po przedruku całości w paryskiej „Kulturze” i druku wybranych fragmentów w zachodnioniemieckim dzienniku „Frankfurter Allgemeine Zeitung”72 Lipski znalazł się w ogniu zmasowanej krytyki reżimowych mediów (dwa dni przed wprowadzeniem stanu wojennego pisał swoją odpowiedź).

Tego samego dnia, gdy przedostał się do strajkujących w „Ursusie”, w „Trybunie Ludu”, organie PZPR, ukazał się kolejny z tekstów pomawiających autora Dwóch ojcayzzn, dwóch patriotyzmón o zdradę. Niejaki Drecki w tekście zatytułowanym Hupka i jego pomocnik napisał: ,,[...] Nie pierwszy to zapewne i nie ostatni przypadek, że głośny artykuł J. J. Lipskiego w paryskiej»Kulturze«s służy jako »pomoc naukowa« propagandzie antypolskich, odwetowych kół w RFN"73.

27 grudnia Lipski na końcu listu do żony, pisanego w areszcie na Rakowieckiej, dziękuje żonie za wsparcie, jakie zawsze od niej otrzymywał, i wspomina o wyborze, jakiego dokonał: „, wiem, że przez te lata Ty płacisz największa cenę i teraz znowu to się nasiliło. Myślę, że dla Ciebie właśnie Wigilia była najcięższa, ale zdaje się, że nam wszystkim nie było lekko.

Wracam Myszko do tego, że zawsze mnie rozumiałaś. Jeśli dziś piszę stąd skąd piszę i w sytuacji, że oczekuję procesu - to moim głównym motywem, który mnie do tego doprowadził, był honor. Zdaje się, że dopiero teraz, na starość, uświadomiłem sobie dokładnie, co to słowo znaczy. Pragmatycznego znaczenia ów poniedziałek sprzed 2 tygodni nie miał. Ale musiałem postapić tak właśnie - i cokolwiek się stanie nie będę żałował, i Ty to rozumiesz" 74 .

\section{Proces „ursuski”}

Lipski bronił się z godnościa, nie zrzekając się odpowiedzialności za uczestnictwo w strajku - przeciwnie, traktując to jako zaszczyt. Zwracał jednocześnie uwagę na próbę uczynienia z jego oskarżenia procesu o charakterze politycznym, skierowanego przeciw KOR.

Na pierwszej rozprawie, 6 stycznia, mówi: „[14 grudnia - przyp. $L$ G] o 14.30 (nie jest to czas dokładny) znalazłem się w Ursusie, ale w akcie oskarżenia przeczytałem, że byłem tam »między 6.00 a $8.00 \ll$, co jest niezgodne z prawda. Jestem filologiem, czytanie tekstów to mój zawód, nie wiem więc, skąd się tam takie oświadczenie wzięło, bo nie padło z moich ust.

Dziwi także stwierdzenie, że »osoby oskarżone nie odstąpiły od działań, organizując rozszerzone zebranie Zarządu, decydujące o strajku okupacyjnym«. Ja tylko chciałem być z robotnikami, w skład Komitetu Strajkowego nie wchodziłem, a więc nie mogłem, jak mi zarzucono, »kierować tym strajkiem«. Otrzymałem propozycję wejścia do Komitetu, ale uważałem, że tam nie ma miejsca dla członka Zarządu Regionu.

Gdybym był w Komitecie, uważałbym to za honor i nie przeczyłbym takiemu faktowi. Dalej - zarzucono mi, że »kierowałem przez wygłaszanie przemówień i nakłaniałem do działań bezpośrednich«. Prawda jest taka, że publicznie, na własne żądanie, poinformowałem obecnych o ich prawach w charakterze zatrzymanych czy świadków - i nic poza tą informacją. Tę instrukcję można przeczytać w kodeksie postępowania karnego, ja to tylko streściłem.

\footnotetext{
${ }^{72}$ J.J. Lipski, Dwie ojczyzny, dwa patriotyzmy, „Kultura” 1981, nr 10, s. 3-29; Der Mythos von dem deutschen „Drang nach Osten” ist unsere Ausflucht, tł. H. Freiherr von Rosen, „Frankfurter Allgemeine Zeitung”, 13 XI 1981.

${ }^{73}$ R. Drecki, Hupka i jego pomocnik. Od naszego korespondenta ₹ Bonn, „Trybuna Ludu”, 14 XII 1981, s. 7.

${ }^{74}$ List Jana Józefa Lipskiego do Marii Lipskiej, dat. 27 XII 81, por. AD JJL, aneks II.
} 
Siedziałem w roku $1964 \mathrm{w}$ areszcie śledczym z sankcją prokuratorską i znam te sprawy, znam prawo, więc moim obowiązkiem było wyjaśnić to innym.

Apel? Tak, wygłosiłem apel: by nie stawiać oporu siłom porządkowym, by nie polała się krew. Byłem uczestnikiem Powstania Warszawskiego, wiele krwi w życiu widziałem...

Nie, nie bałem się o siebie, ale wiedziałem, że opór byłby tragedią. To był apel o to, by uniknąć najgorszego. Inkryminowana mi sinformacja propagandowa«? Nie wiem, o co tu chodzi, ograniczyłem się bowiem do dwu wymienionych elementów"75.

Lipski w swojej mowie obrończej zwrócił też uwagę na charakterystyczne błędy w nazwisku, wskazujące być może na intencję ukarania nie jego personalnie, a po prostu - kogoś z KOR (można podejrzewać, że wskazywało to na politykę władzy, aby przedstawić KSS „KOR” jako organizację terrorystyczna): „Uderza mnie tu jeszcze jedna rzecz: w akcie oskarżenia napisano, że "przemawiał« - raz LITYŃSKI, raz LIPIŃSKI. Nie był to ani mój przyjaciel Jan Lityński, ani stary prof. Edward Lipiński, ani jego syn, nie byłem ja.... A może to swoisty błąd korektorski?".

W tym momencie, jak odnotowano, ,J.J. Lipski poczuł się źle i poprosił o $15 \mathrm{~min}$. przerwy, co sąd uwzględnił”. Po przerwie Lipski powiedział, że nadal czuje się źle, i że w zasadzie skończył, nie ma nic więcej do dodania. Mówił: „odmawiam udzielania dalszych odpowiedzi, to niczego nie wyjaśnia ani nie zmienia, a ja się bardzo źle czuję”.

Do 15 stycznia 1982 roku schorowany Lipski „brał udział w codziennych wielogodzinnych rozprawach i był po parę razy dziennie przeprowadzany w kajdankach przez kilka kondygnacji schodów do sali sądowej"76. Sąd zarządził zbadanie Lipskiego przez biegłych lekarzy poza szpitalem więziennym dopiero 14 stycznia. Bardzo obrazowo opisywał to Kaniewski: „wozili nas do sądu na Lesznie z 10 razy. Na początku razem z Lipskim, mimo że był tuż po zawale i ledwo trzymał się na nogach. W jego sprawie odbyła się autentyczna farsa. Dwóch utytułowanych lekarzy-ekspertów toczyło akademicki spór na temat jego serca. A toczyli go długo i zażarcie, wyrywali sobie elektrokardiogramy, nie mogli się dogadać, czy zastawka działa prawidłowo - i po paru godzinach nikt, łącznie z wysokim sądem, nie wiedział co jest grane. W końcu wyłączono go z procesu i odesłano do więziennego szpitala" 77 .

Wtedy właśnie, staraniem obrońcy (był nim Jan Olszewski ${ }^{78}$ ), Lipskiego wyłączono ze sprawy „piątki”. Nie był on z tego do końca zadowolony, martwiąc się o los współoskarżonych, bagatelizując własne dolegliwości; 17 stycznia napisał do żony: „tak prawdę mówiąc, to nie wiem, czy to wyłączenie, które wywojował na sprawie Janek [Olszewski] jest dla mnie korzystne. Była to jednak pewna atrakcja te jazdy do sądu; z współtowarzyszami coraz bardziej zżywałem się, a i obejrzenie z daleka znajomych i życzliwych twarzy też nie jest bez znaczenia, a tak nawet Ciebie i Aśki nie będę w najbliższym czasie widywał. A ponadto jakoś to było bardziej elegancko, gdy siedzieliśmy w piątkę. Moja wydzielona sprawa - to już nie to. [...]

Mam nadzieję, że jutro będę miał widzenie z Jankiem, może więc omówimy moją sytuację procesową - i zmienię zdanie, ale jak dotąd nie jestem zadowolony z rezultatu, tym bardziej, że akurat wobec stawania przed sądem itp. jestem bardziej odporny, niż lekarze zakładaja, moje zaś dolegliwości wiązały się z przemęczeniem na komendzie Ochota. No, ale jak zawsze polegam na adwokackiej głowie Jana.

Martwi mnie też, że chłopcom z Ursusa - moim współoskarżonym - ubyło zapewne publiczności na sali. To też wprowadza pewne ożywienie, nawet jeśli są to nieznane twarze”79.

Wyrok przeciw „chłopcom z Ursusa” zapadł już trzy dni po tym, jak Lipski pisał swój list - 20 stycznia. Mimo jego surowości - 3,5 roku więzienia (nie w zawieszeniu!) dla Kaniewskiego, po 3 lata dla Czerwińskiego i Kaszuby - Prokurator Generalny PRL wystapił z rewizją nadzwyczajną ze względu na zbyt niski wyrok. W apelacji nazwano to „rażącą niewspółmiernością w stosunku do wysokiego stopnia niebezpieczeństwa społecznego” z uwagi na

\footnotetext{
75 AIPN, 960/1336, k. 52.

${ }^{76}$ List Marii Lipskiej do biskupa Bronisława Dąbrowskiego, Sekretarza Episkopatu Polski, AD JJL, poz. 1475.

${ }^{77}$ E. Poliński, Póki żyjemy..., s. 11-12.

${ }^{78}$ Czerwińskiego bronili Andrzej Grabiński i JerzyWoźniak, Kaniewskiego - Władysław Siła-Nowicki i Witold Ferfet, Kaszuby

- Stanisław Szczuka (por. AIPN, 754/258).

${ }^{79}$ List Jana Józefa Lipskiego do Marii Lipskiej, dat. 17 I 82, por. AD JJL, aneks II.
} 
wielkość zakładów w Ursusie; wobec tego kara jest „rażąco łagodna”"80. Pismo podpisał zastępca prokuratora generalnego, Józef Ostaś.

Adwokaci Władysław Siła-Nowicki i Jerzy Woźniak zwracali uwagę na fakt, podważający jakiekolwiek oskarżenia z tytułu dekretu o stanie wojennym - sam dekret wydrukowany został z datą 14 grudnia, ale była to przecież data „fikcyjna i nieprawdziwa”, ponieważ Dziennik Ustaw nr 29 nie został ogłoszony do dnia 18 grudnia! Wnioskując zatem o uniewinnienie aresztowanych, napisali m.in., że „powoływanie się niektórych wyroków sądowych na środki masowego przekazu: radio i telewizję, jako źródło mocy obowiązującej prawa karnego jest żenujące. Należy przypomnieć, że za wyrażanie takiego poglądu obcina aplikanta bez litości każda najłagodniejsza nawet komisja egzaminacyjna”. Mimo logiki wywodu, nie udało im się doprowadzić do zmiany decyzji sądu. 24 września 1982 r., po pół roku procedowania, Sąd Najwyższy oddalił rewizję (zdanie odrębne zgłosił sędzia Józef Tobera, prawdopodobnie właśnie w intencji złagodzenia wyroku $\left.{ }^{81}\right)$.

Jan Józef Lipski, mimo wyłączenia go z procesu, wciąż przebywał w areszcie, leczony w klinice kardiologii w Aninie. W marcu 1982 r. został zwolniony z pracy (z mocy prawa, na skutek nieobecności - spowodowanej aresztowaniem). Sprawa przeciwko niemu wciąż była prowadzona jako wyłączona ${ }^{82}$.

Po wielu staraniach otrzymał wreszcie w maju 1982 r. zgodę na wyjazd na operację do Londynu (w areszcie spędził blisko pół roku - zwolniony został 20 maja). MSW niechętnie się na to zgodziło, ponieważ nie znaleziono lekarza i szpitala w PRL, który mógłby wykonać konieczną operację. Mecenas Olszewski otrzymał z sądu nakaz dostarczenia w ciagu pięciu dni dowodów potwierdzających staranie się Lipskiego o wyjazd na leczenie do Wielkiej Brytanii (co jednoznacznie wskazuje, że władze nie chciały Lipskiego wypuścić na wolność, a tylko na leczenie poza krajem - a może w ogóle poza kraj).

Ryzyko śmierci oskarżonego było politycznie chyba zbyt wielkie (przygniatająca większość więziennej dokumentacji Lipskiego stanowią informacje medyczne); może zresztą liczono, że Lipski nie powróci? On jednak, wykorzystawszy pobyt w Londynie nie tylko na operację, ale też na napisanie ksiażki dokumentującej działalność KOR - na wiadomość o planowanym procesie „przywódców” KOR (do których go zaliczono) - powróci do kraju, gdzie znów trafi do więzienia. To jednak już inna historia ${ }^{83}$.

\section{Bibliografia}

A. Paczkowski, Wojna polsko-jaruzelska. Stan wojenny w Polsce 13 XII 1981 - 22 VII 1983, Warszawa 2007

AIPN 481/49/CD/1

AIPN, 480/1

AIPN, 480/3

AIPN, 480/5

AIPN, 480/6

AIPN, 754/258

AIPN, 960/133

E. Poliński [A. Gelberg], Póki żyjemy..., Warszawa 1986

\footnotetext{
${ }^{80}$ AIPN, 754/258.

${ }^{81}$ Sędzia Tobera, podzielając zdanie odrębne sędziego Sądu Wojewódzkiego, E. Baworowskiego, powołując się na zeznana świadków, w tym dyrektora „Ursusa”, H. Wilka, wskazywał, że faktycznie „Ursus” „stał”, a tłumaczenie oskarżonych, że chcieli „ucywilizować” protest, nie dopuszczając do „dzikich” strajków, które mogłyby skończyć się walką - i mieli na celu chronienie majątku zakładu - jest potwierdzone licznymi zeznaniami świadków; argumentował, że sprawa powinna wrócić do Sądu Wojewódzkiego (chyba z intencją złagodzenia kary). 24 XII 1982 r. dyrektor Biura Orzecznictwa Sądu Najwyższego dr B. Bartosik stwierdził jednak, że „wyrok [...] jest w pełni prawidłowy [...] i nie nasuwa zastrzeżeń”, które podnosił sędzia Tobera. Skazani odbywali wyrok w więzieniu w Łęczycy, a później Hrubieszowie i Białołęce. Zwolnieni zostali na mocy amnestii - Kaszuba w lipcu 1983 r., Kaniewski 14 września 1983 r. (nie dotarłem do informacji dotyczących Czerwińskiego). ${ }^{82}$ Nosiła sygnaturę IV K. Dor. 255/81.

${ }^{83}$ O Lipskim jako działaczu „Solidarności” por. T. Ruzikowski, Jan Józef Lipski-człłowiek Solidarności (1980-1987), [w:] Jan Józef Lipski zperspektymy XXI wieku, red. K. Rokicki, Warszawa 2012.
} 
Encyklopedia „Solidarności” wersja internetowa: http://www.encyklopedia-solidarnosci.pl/wiki/index.php? title=TL-1980/10)

Instytut Badań Literackich Polskiej Akademii Nauk, Dział Kadr, 519/82 (teczka osobowa Jana Józefa Lipskiego), IV K. Dor. 255/81

J. Domżalski, M. Jarosiński, Gdy chcielismy być wolni. URSUS w latach 1980-1989, Warszawa 2010

J.J. Lipski, Dwie ojcryzny, dwa patriotyzmy, „Kultura” 1981, nr 10, s. 3-29; Der Mythos von dem deutschen „Drang nach Osten” ist unsere Ausflucht, tł. H. Freiherr von Rosen, „Frankfurter Allgemeine Zeitung”, 13 XI 1981

J.J. Lipski, Pamiéc murón. Warszawa 1987 - 1944, [w:] idem, Pisma polityczne. Wybór, oprac. Ł. Garbal, Warszawa 2011. J.J. Lipski, Wyznania, oprac. M.D. Pieńkowska, „Polityka” 1992, nr 3

M. Głowiński, Kregi obcości. Opowieś́ć autobiograficz̨na, Kraków 2010

M. Jędrzejko, M.L. Krogulski, M. Paszkowski, Generatowie i admiratowie III Rzeecsypospolitej: 1989-2002, Warszawa 2002

M. Srebrny, Strajk 14 grudnia 1981 roku - wspomnienia Mariana Srebrnego, [w:] J. Domżalski, M. Jarosiński, Gdy chcieliśmy być wolni. Ursus w latach 1980-1989, Warszawa 2010

R. Drecki, Hupka i jego pomocnik, „Trybuna Ludu”, 14 XII 1981

B. Sieradzki, Zwalcranie nielegalnej dziatalności NSZZ „Solidarność" w obiektach gospodarki narodowej w latach 1981-1984 na prayykładzie Zakładów Mechanicznych „Ursus”, praca dyplomowa, Warszawa 1989 (AIPN, 001708/3699)

T. Ruzikowski, Jan Józef Lipski - człowiek Solidarności (1980-1987) [w:] Jan Józef Lipski zperspektyny XXI wieku, red. K. Rokicki, Warszawa 2012

T. Ruzikowski, Stan wojenny w Warszawie i w wojewódz̨twie stotecznym 1981-1983, Warszawa 2009

W. Kulerski, Bardzৃo dtugi spacer z.psem, rozmawiał A. Friszke, „Wolność i Solidarność” 2012, nr 3

W. Polak, Opór spoteczny w pierwssych dniach stanu wojennego, „Wolność i Solidarność” 2012, nr 3 